\title{
Revisiting the School-Based Management Recent Studies
}

\author{
Kyaw Zay Ya ${ }^{1}$, Muhammad Giatman ${ }^{2}$, Fahmi Rizal $^{3}$, and Rizky Ema Wulansari ${ }^{4}$ \\ ${ }^{1234}$ Universitas Negeri Padang, Indonesia \\ * e-mail : kzayya111@gmail.com
}

\begin{abstract}
This paper aims to review the School-Based Management in recent studies. As the research method, the researcher follows the systematic procedures for literature review articles such as collecting data, reviewing, categorizing, and presentation. This paper answers the three questions: (A) definition of SBM, (B) factors considered to implement SBM, and (C) the roles of practitioners. Data is based mainly on secondary data, published papers in international journals in particular. In the findings, the researcher presents a certain definition of SBM defined by prior researchers, authority sharing, facility and infrastructure management, budget management, autonomy, transparency as well as the roles of school players, in-depth and breadth. Eventually, the recommendations are also appointed for further studies to promote the School-Based Management literature.
\end{abstract}

Keywords: School-based management; autonomy; transparency; authority sharing derivative works and remixes based on it only for non-commercial purposes.

\section{INTRODUCTION}

Education plays an important role in the world we live in. To provide the better education, educational management system is a basement. Education management system has changed a lot since many decades ago through Industrial Revolution 1.0 till 4.0. Last two decades can be called as the witness decades in changes of school management sector (Elmelegy, 2015). Among changes, it is obvious that School-Based Management (SBM) has made education quality transformative around the world (Bandur, 2012). There are four broad arrays of educational approaches, namely, innovation and inconsistency, focusing on the markets and standardization, emphasizing on the performance and partnership as well as the retention and abandonment based on the first three approaches (Hargreaves \& Shirley, 2009) as cited in (Caldwell, 2015). The illustration of these approaches through the timeline is shown below.

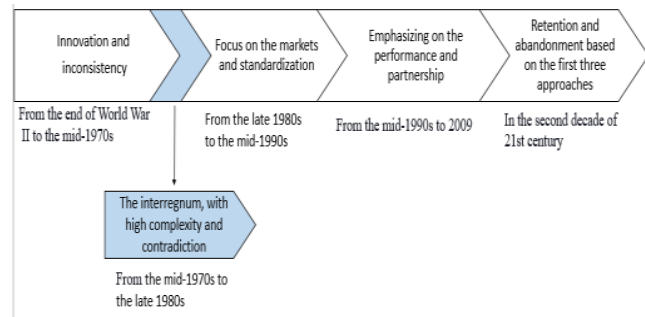

Figure 1.

Four educational approaches (Hargreaves \& Shirley, 2009) as cited in (Caldwell, 2015)

Firstly, "innovation and inconsistency" was perceived from the end of World War II to the mid-1970s, and "the interregnum" from the mid-1970s to the late 1980s with a high level of complexity and contradiction. Secondly, "focusing on the markets and standardization" was admited from the late 1980s to the mid1990s. Thirdly, "emphasizing on the performance and partnership" was shifted from the mid-1990s to 2009. These three educational changes were examined by several segments such as controlling, purpose, trust, community engagement, curriculum development, teaching and learning surroundings, professionalism, professional 
learning communities, assessment and accountability, and lateral relations. Finally, "the retention and abandonment based on the first three approaches" was formed in the second decade of $21^{\text {st }}$ century. Retention refers to more focusing on the good things learned from previous experiences such as partnership, public relations, financial management, teaching and learning methods, and so forth, whereas the autocracy and centralized system are involved in the abandonment segment.

Reducing the autocracy in the school management system and enhancing the decentralized system at the same time, the educational experts believe that school players on the ground can perform well to meet the society needs in a timely manner, with the effective methods (Santibañez et al., 2014). Centralized hierarchical system can reduce quality of outcome in creativities and innovations (Karmila \& Wijaya, 2020). This kind of system minimizes the authority of school players on the ground. It means that practitioners need to report everything about school conditions to the head offices. In that situation, several common problems used to happen, such as time delay, hesitation of work procedure, etc., through the management activities. Thus, Karmila \& Wijaya pinpointed that authority limitation is one of the facets towards the low quality education.

Empowering the authority in decision making at the school level, principal-teachercommunity formal alliance works together to provide quality education. School principals and teachers entail both management and leadership in the school (Caldwell, 2015). The six segments of school-basedmanagement, namely school leadership, internal stakeholders' participation, external stakeholders' participation, school-based resources and school performance accountability (Pepito \& Acibar, 2019). The factors encouraged by the SBM are a large pace of authorities for the school players such as optimal stakeholder involvement, clear information systems, and reward system (Jaelani \& Masnun, 2019). Therefore, SBM has taken into account for quality education.

\section{RESEARCH OBJECTIVES}

This paper aims at reviewing the ShoolBased Management recent studies to promote the SBM technique. Even if this is not a sufficient worthy of enomous articles, the objectives of this work are to be a small part in the development of SBM literature. In regard to the SBM, this paper explained about how the prior researchers define the School-Based Management, the factors considered for implementing School-Based Management at School, and the roles of main players in School-Based Management.

\section{METHODS}

This is a literature review article based on the existing literature of the school-based management and related field. As the research method, researcher pursues the systematic procedures such as data collecting, reviewing, categorizing, and presentation suggested by Bryman \& Bell (2015). The data is mounted only on the secondary data, especially published articles in the international journals. The type of paper is limited by choosing the terms of school-based management (SBM) and school management. Researcher reviewed 31 articles in total in which 24 articles are pure SBM and 7 remainings are closely related to the school management such as educational supply chain, the roles of school heads and PTA, etc. Question (A) is answered by randomly selecting the several definitions among many articles. To answer the question (B), researcher follows the instruction of Karmila \& Wijaya (2020) in which the three portions are classified to examine the SBM implementation, namely school management, teaching and learning process, and community relations. For question (C), the researcher groups the three types of school player under the existing literature such as principal, teacher, and the community.

\section{FINDING AND DISCUSSIONS}

\section{Definition of School-Based Management (SBM)}

In the school-based management, responsibility for, and decision making over, school operation is transferred to principals, teachers, parents, community, and sometimes 
students (The World Bank, 2007). Schoolbased management as an educational management which provides more authority to the schools for allocating and managing the available resources by involving the collaboration and support of various parties towards the quality education (Ho, 2010); (Karmila \& Wijaya, 2020). SBM is the concept which comes up with autonomy to determine the school policy to enhance the performance quality of the school, with immediate cooperation among various stakeholders such as school, community, and government (Mawanda et al., 2018). Besides, SBM is an institutional approach that extends the responsibility and authority at the school level for the effective performance of the school (Elmelegy, 2015). SBM as a form of formal decision-making authority in managing the school functions such as budget planning, personnel, and programs (Sihono \& Yusof, 2012). The school which is composed by the site-level actors, with adequate autonomy and flexibility, can facilitate the schools to gain the goals, and to meet the targets by optimizing the cooperation between them.

According to the literature, there are common goals of SBM implementation at school. The academic experts set these goals. All of these can be seen under the basic norms: 1) To devolve the authority to the school level officials for realizing the decision in managing and supervising the school activities to meet the local needs and 2) to enhance the involving of various stakeholders through the school operations including the use of public fund towards transparency and accountability.

\section{Factors Considered to Implement SBM at School}

There are three portions in this section. In order to divide the three portions, the researcher followed the instruction of (Karmila \& Wijaya, 2020). In their study, they utilized the descriptive qualitative method to provide the in-depth explanations on the implementation of SBM. Three segments they developed are school management, teaching and learning process, and community relations.

\section{a. Vision, Mission, and Objectives Setting}

Vision, mission, and objectives are the foundations to implement the school-based management against the ordinary system (Karmila \& Wijaya, 2020) and (Bandur, 2012). Vision and mission are set by the cooperation of principal, teachers, and school committee. The preparation of the vision and mission was followed by socialization to let all school members understand the outlines of vision and mission. Respondents in their study stressed that they have the strong experience in decision making for setting mission (96\%), vision (96.2\%), and objectives (95\%) respectively (Rini et al., 2019). Besides, demostrated the significant relationship between the role of principal, and school's vision and mission (Vally \& Daud, 2015). They stated that the scope of the school vision and mission are needed to be clear, explicit, and coherent. Effective vision often focusses on teaching-learning following the international standards and benchmarks of the students' performance and curriculum syllabus (Elmelegy, 2015).

\section{b. Educational Standards}

The standards are needed for all school functions (Mawanda et al., 2018). The school they researched has framed the standards according to the National Education Standards (NES) such as content standards, competency standards, process standards, assessment standards, equipment and infrastructure standards, educator standards and education personnel, management standards, and financing standards. It indicates that a particular school should construct the school functions under national education standards. The joint solution of SBM and StandardsBased Accountability (SBA) have a dramatic outcome on the student achievement. SBA is defined as the school accountability system based on the academic standards (Camminatiello et al., 2012).

\section{c. Facility and Infrastructure}

Adequate facility and infrastructure are also important for the school. The comparative case study on the school management in two schools; the one in the USA and the other in Turkey. In their study, one of the reasons why Turkish teachers are not happy at school is due to poor physical conditions. A clean, neat, beautiful school and pleasant conditions are the good images of the school (Jaelani \& Masnun, 
2019). The supporting of facility and infrastructure is included to determine the effectiveness of SBM. As the school they conducted has no library, it is difficult to facilitate reading literacy spaces for the students (Karmila \& Wijaya, 2020). They also then pointed out the lack of the use of ICT at school. As the result, every school member cannot access the school information in a timely manner. There is no laboratory at the school where they researched. They noted it as an obstacle to practice experiments for the learners (Mawanda et al., 2018). Besides, the study results revealed that the lack of school facilities is a big deal (Bandur , 2012). For these reasons, it is obvious that poor facility and infrastructure can hesitate the acceleration of teaching and learning process.

\section{d. Budget Management}

What are the sources of budget in SBM system? This is a highly considerable question for the beginner SBM players. SBM is the kind of system provides cash-grants to the school (Santibañez et al., 2014). The government devolves the authority to the school level officials, especially to the school principal, and the principal in return shares the authority to the stakeholders (Comm \& Mathaisel, 2008). Authorized school personnels are also responsible for finding funds to operating the school functions. Thus, the public school which implements SBM is likely to be the same with the operation of a private school. School needs to find budget for operation themselves. On the other hand, students and their custodians look for school environment safety, up-to-date residence halls, modernized facilities, and high technology. For offering these resources, school tuition fees rise each year, and as the result, students and their families achieve the best outcomes in return.

Budgeting is the most important task area followed by staffing, curriculum and instruction, goals, and organizational structures (Kiragu et al., 2013). Besides, School-based Finance (SBF) plays a crucial segment in SBM (Ho, 2010). Developing the curriculum and staff allocation largely relate to the budget control (Moradi et al., 2012). Regarding with the sources of fund, school budget is supported by both the government and the community (Mawanda et al., 2018). The governments do not completely cut off the funds for public schools (Rini et al., 2019). Several limited amounts are still supported to schools. On the other hand, business marketing strategy is also linked to the school fundrising. Many schools have promoted the educational brand development to serve the customers (students and society) (Pathak \& Pathak, 2010). Funds can be raised from producing school brochures, calendar, marketing campaigns, and using agents through the strategic brand development. In addition, school budget could also be increased by "outsourcing". It refers to lending school canteen space to the third-party businesses, bookstores, convenience stores, printer shops, photo copy shop, and etc. (Comm \& Mathaisel, 2008). School principal provides the teachers extra tasks including handling the school budget (Jaelani \& Masnun, 2019). School budget is only used per the plan agreed by all members, but not allow for the activities which are not approved. Thus, the transparency between all stakeholders is at the highest level.

\section{e. Learner Management}

Student management aims to operate learning activities smoothly. Three major tasks to be paid attention, namely new students' admission, learning progress activities as well as guidance and coaching discipline (Jaelani \& Masnun, 2019). The special service management which includes library service, healthcare service and campus safety (Jaelani $\&$ Masnun, 2019). There are direct and indirect services for the learners in the school. The former covers the student design and development, student admission, academic and non-academic trainings, practical trainings, result testing and further development. The later refers to the campus development and maintenence, IT infrastructure, hostel, cleaning, book stores, security service, restaurants and sport facilities, etc.

\section{f. Leadership and Administration in SBM}

The readiness of school principals is highly important in SBM (Vally \& Daud, 2015). The more effective the principal plays his role, the more efficient the vision and mission and the more productive the human resources management. The school board and superintendents must be supportive of SBM, 
with the trust on the councils and principals while they implement district level goals in the particular schools. It is crucial to clearly and explicitly describe the roles and responsibilities for each member against conflicts between them. Furthermore, the trainings and practical knowledge in such areas as problem solving, decision-making, financial management and group dynamics are required for all participants, including school staffs, teachers, and community members (Ho, 2010). The council members must be able to collaborate in the planning and budget matters. This helps principals and teachers focus on their jobs in other aspects. Wohlstetter indicated the findings of AASA/NAESP/NASSP task force in which the districts which has had successfully implemented SBM focused mainly on the two highly expectations-greater involvement in decision making process and making "better" decisions. Thus, the principal needs the advanced leadership skills and other required trainings. Many scholars agreed that the principal is defined as evaluator, manager, administrator, leader, supervisor, innovator, and motivator.

\section{g. Risk Management}

Risk management is needed to be taken into consideration in SBM (NASBM, 2015). Principal and school committee are reminded not to ignore how to handle possible risks at school. To be ensure effective risk management, school players should prepare since early in the beginning of the initiation of SBM at school such as financial risks, healthcare, security system, etc. Concerning the procurement risks. School-supplier relationship should be arranged for long term contracts, tenders, and agreements for more bargaining power (Comm \& Mathaisel, 2008). Additionally, school environment should be planned to be sustainable and ecofriendly. Besides, risk analysis is a tool for classifying, characterizing, and evaluating the possible losses from the events (Dickerson \& Ackerman, 2016). With the facility maintenance management, school administration-based risk management is also needed to be considered. Consequently, risk managements for both physical materials and management activities should be taken into account.

\section{h. Teaching and Learning Process}

Decentralization in SBM does not mean all functions are completely delegated to the schools, but some functions are still in hand of the authority and responsibility of the Government, provincial governments, district/city governments, and some other functions are consigned to the schools (Rini et al., 2019). Concerning this, a particular school which begins to implement SBM must work within the boundry under the government. According to (Winarti, 2011) and Bandur (2012), Indonesia government has passed Education Acts (Undang-undang tentang Pendidikan Nasional), which was followed by the guidelines of its implementation. By these regulations, the government assigned National Education Standards Board to standardize the contents of the curriculum and the graduate competencies. Winarti (2011) stated that the curriculum is adjusted and modified by school committee at the school level, which is known as the School-Level Curriculum. Additionally, the Education Laws describe that students have to take national exam held by the government, which aims at measuring the students' competencies, at the end of each level, (elementary school, junior and senior high school). But the schools have the autonomy to decide whether the students pass or fail the exam.

Since today age is the Industrial Revolution 4.0, teaching methods and learning styles have slightly changed. The use of projector replaces the blackboard and whiteboard. Microsoft word and Pdf files replace the paperwork. Even in this Coronavirus outbreak situation, video conferencing via internet replaces the face-toface teaching in the classroom. Internet has widely received as a learning resource for education (Nuncio et al., 2020). Students and teachers can easily access the required data from the internet. It helps them facilitate the teaching and learning process. Moreover, there are teaching tools such as mobile learning, game-based learning, etc. Therefore, the $21^{\text {st }}$ century SBM schools should also adopt the newly teaching methods towards the effective outcomes. 
i. Community Relations and Decision making Many scholars agree that the community involvement in decision making process plays an important role in SBM. Community relations consist of parental involvement, business enterprise, funding agencies (NGO, INGO, and donors) in general. The school council is comprised by various stakeholders from different sectors and they participate in the school activities. There are four elements of participatory management (Sihono \& Yusof, 2012). These segments are power, information, reward as well as knowledge and skills (Mohrman et al., 1992). Among all stakeholders, principal delegates these four components towards the student achievements, increasing the attendance rate, reducing dropout rates and disciplinary actions to the learners. In case, some obstacles related to the parental education background (Winarti, 2011). In some remote places, the communities tend to be less developed. They might have problems related to the representativeness and the membership of the committee. Nevertheless, parents-teacher association is a vital pillar of SBM (Moradi et al., 2012) and parents-teachers-association (PTA) has a significant influence on the school management activities in his study (Okendu, 2012).

Community relations and decision making process cannot be separated due to implementing the collaboration, transparency, and accountability. Decisons were made on the basis of consensus (Bandur, 2012). However, there are some challenges in decision making (Mawanda et al., 2018). Even some teachers do not have sufficient knowledge about SBM. It tends to lead towards low performance of SBM. Thus, most researchers mentioned provision of relevant trainings is a must, perhaps quarterly or yearly, in lines of finance management, decision making, problem solving and so forth. The problem in decision making is authority controlling by the principal alone. Teachers in both Turkey and the USA stated that they are allowed to participate in decision making process but the final decision is made by only principal. The result of student achievement in SBM schools has been stagnant due to incompatibilities between policy and practice in the decentralization of Nepal education sector (Joshi, 2018). Besides, PTA and school board do not correlate with the school management system although PTA is an important factor in SBM (Okendu 2012).

\section{The Roles of Practitioners}

\section{a. The Roles of Principal}

The role of principal is a critical point in SBM system. School can be seen as educational service provider and principal can be seen as education manager, evaluator, administrator, leader, supervisor, innovator, and motivator (Elmelegy, 2015); (Jaelani \& Masnun, 2019); (Joshi, 2018); (Kiragu et al., 2013); (Mawanda et al., 2018); (Pepito \& Acibar, 2019); (Rini et al., 2019); (Sihono \& Yusof, 2012); \& (Winarti, 2011). As an evaluator, the principal evaluates the student learning outcomes and performance of teachers. As a manager, the principal allocates and assigns both human resources and material resources available for teaching-learning activities. As an administrator, the principal administers the documental works by both paperwork and technological aid works. As a leader, the principal develops vision, mission and school goals, with teachers and school committees. As a supervisor, the principal can observe the teachers' ability and supervise well them. As an innovator and motivator, the principal creates the innovative ideas and policies which make the school effective, and motivates teachers and parent's representatives towards sustainable school development goals. Principal takes part in almost all aspects such as structures, roles, systems, instructional practices, human resource practices, and the skills and knowledge of participants (Sihono \& Yusof, 2012).

\section{b. The Roles of Teacher}

The roles of teachers are for supporting the roles of principals in light of decision making and implementing teaching programs. Teachers work under the supervision and management of the principal (Mawanda et al., 2018). Teachers and principal share information, knowledge, and skills on the new strategies, planning, organizing, and extra curricula tasks (Sihono \& Yusof, 2012). The principals and teachers collaborate in their tasks (Kiragu et al., 2013). They also recommended teachers and principals should 
actively involve in decision making. Teachers can act as educators who are obliged to foster learners (Mawanda et al., 2018). In SBM, teachers must improve their professional skills themselves to enhance the quality of education, according to Indonesia's 2003 Education Law No. 20.

\section{c. The Roles of community}

Parental involvement is a top-tier part in the roles of community of SBM system. They cooperate with teachers and principal in teaching, learning, campus development, school activities, and so forth (Sihono \& Yusof, 2012). In the traditional ways, parents are not allowed to influence or to make decision in the key school-level matters such as teacher training, teacher hiring and firing, pedagogy, etc (Santibañez et al., 2014). Community involvement can be divided into several portions such as planning committee, documentation committee, food and snacks committee, evaluation committee, and so on (Pepito \& Acibar, 2019). External stakeholder participation can be cooperated with joint managements under school management system. Parent monitoring has been received as an effective tool to administer the school level inputs such as the increasement of teacher attendance in India and El Salvador (Duflo et al., 2011); (Jimenez \& Sawada, 1999) as cited in (Santibañez et al., 2014). The broad network could effectively impact on the betterment of the school. For example, in this coronavirus outbreak around the world, WHO, UNDP, CDC and many other humanitarian organizations remind the students' parents to kindly participate in the teaching-learning process at home assigned by local government and school committee such as e-learning, mobile learning, etc.

\section{CONCLUSION}

SBM sounds complex. Principal cannot sit on his/her chair calmly. Teachers's duty is not only for teaching. Students's duty is not just for learning. Parents cannot stay home by doing their businesses. Donors, NGO, and INGO also have extra tasks even if their job is to assist the local people. If the teachers are assigned extra tasks outside of teaching, it might happen contradictions between the principal and teachers. Besides, other factors, such as lack of appropriate professional development for the school leaders, lack of school facilities and inadequate finances, are the problems in SBM system. Furthermore, if SBM is considered to implement in the lessdeveloped country like Myanmar, the government should have already completed enlightenment seminars to parents by taking a certain time before introducing the SBM system.

This work might leave some unanswered matters because only 31 articles could be reviewed. It might be inadequate of the excellent literature review paper. As the result, researcher highly recommends the future researchers to proceed the greater reviewing works with sufficient data and also gently remind for those, who tends to conduct the research on SBM implementation. The results of this attempt would be beneficial for the SBM literature, school heads, educators, policy makers, etc. Researcher believes that the total number of many firewoods could be a fascine although a single firewood couldn't be. Likewise, this attempt would be a small part so as to support the SBM literature.

Many SBM studies have been emerging over time. In these papers, most researchers commonly applied qualitative method, descriptive method, and qualitative approach with descriptive method to explore SBM. The number of studies presented from the perspectives of quantitative and mixed methods still lacks in the SBM literature. Besides, the research investigations and evaluations related to the risk management in SBM system are still scanty literatures.

\section{REFERENCES}

Bandur, A. (2012). School-based management developments and partnership: Evidence from Indonesia. International Journal of Educational Development, 32(2), 316328.

https://doi.org/10.1016/j.ijedudev.2011.05 .007

Bryman, A., \& Bell, E. (2015). Business Research Methods. Oxford Univ Press.

Caldwell, B. J. (2015). School Management. In International Encyclopedia of the Social \& Behavioral Sciences: Second Edition (Second Edi, Vol. 21). Elsevier. 
https://doi.org/10.1016/B978-0-08097086-8.92069-5

Camminatiello, I., Paletta, A., \& Speziale, M. T. (2012). The effects of school-based management and standards-based accountability on student achievement: Evidence from pisa 2006. Electronic Journal of Applied Statistical Analysis, 5(3), 381-386. https://doi.org/10.1285/i20705948v5n3p3 81

Comm, C. L., \& Mathaisel, D. F. X. (2008). Sustaining higher education using WalMart's best supply chain management practices. International Journal of Sustainability in Higher Education, 9(2), 183-189.

https://doi.org/10.1108/146763708108563 23

Dickerson, D. E., \& Ackerman, P. J. (2016). Risk-based Maintenance Management of U.S. Public School Facilities. Procedia Engineering, 145, 685-692. https://doi.org/10.1016/j.proeng.2016.04.0 69

Duflo, E., Dupas, P., \& Kremer, M. (2011). Peer effects, teacher incentives, and the impact of tracking: Evidence from a randomized evaluation in Kenya. American Economic Review, 101(5), 1739-1774.

https://doi.org/10.1257/aer.101.5.1739

Elmelegy, R. I. (2015). School-based management: An approach to decisionmaking quality in Egyptian general secondary schools. School Leadership and Management, 35(1), 79-96. https://doi.org/10.1080/13632434.2014.96 2499

Hargreaves, A., \& Shirley, D. L. (2009). The Fourth Way: The Inspiring Future for Educational Change. Corwin Press.

Ho, H. (2010). The Prospects for the Implementation of School-Based Financial Management in Taiwan. International Education Studies, 3(1), 145-150.

https://doi.org/10.5539/ies.v3n1p145

Jaelani, A., \& Masnun, M. (2019). The Implementation of School Based Management in Madrasah Ibtidaiyah. $A l$ Ibtida: Jurnal Pendidikan Guru MI, 6(2),
$256-270$.

https://doi.org/10.24235/al.ibtida.snj.v6i2. 3793

Jimenez, E., \& Sawada, Y. (1999). Do Community-Managed Schools work? An evaluation of El Salvador's EDUCO Program. The World Bank Economic Review, 13(3), 415-441. https://doi.org/10.1093/wber/13.3.415

Joshi, D. P. (2018). Does School-Based Management Help to Improve Quality of Education? A Case of Student Achievement in Nepal. Educational Process: International Journal, 7(4), 228-236. https://doi.org/10.22521/edupij.2018.74.1

Karmila, N., \& Wijaya, A. (2020). Implementation of School Based Management in Tambilung Elementary School. Jhss (Journal of Humanities and Social Studies), 4(1), 71-73. https://doi.org/10.33751/jhss.v4i1.2044

Kiragu, J. W., King'oina, J. O., \& Migosi, J. A. (2013). School-based management prospects and challenges: A case of public secondary schools in murang'a south district. International Journal of Asian Social Science, 3(5), 1166-1179.

Mawanda, V., Karta, I. W., \& Zm, H. (2018). Effectiveness of Implementation of School-Based Management In Elementary School 1 Puyung Central Lombok. IOSR Journal of Research \& Method in Education (IOSR-JRME), 8(3), 55-61. https://doi.org/10.9790/7388-0803025561

Mohrman, S. A., Lawler, E. E., \& Mohrman, A. M. (1992). Applying Employee Involvement in Schools. Educational Evaluation and Policy Analysis, 14(4), 347-360. https://doi.org/10.3102/016237370140043 47

Moradi, S., Hussin, S. Bin, \& Barzegar, N. (2012). School-Based Management (SBM), Opportunity or Threat (Education systems of Iran). Procedia - Social and Behavioral Sciences, 69(Iceepsy), 21432150.

https://doi.org/10.1016/j.sbspro.2012.12.1 79

NASBM. (2015). School business management competency framework. 
Nuncio, R. V., Arcinas, M. M., Lucas, R. I. G., Alontaga, J. V. Q., Neri, S. G. T., \& Carpena, J. M. (2020). An E-learning outreach program for public schools: Findings and lessons learned based on a pilot program in Makati City and Cabuyao City, Laguna, Philippines. Evaluation and Program Planning, 82(June), 101846 https://doi.org/10.1016/j.evalprogplan.202 0.101846

Okendu, J. N. (2012). The Role of School Board , School Heads and ParentTeachers Association in the Effective Management of Public Schools. 3(8), 201-208.

Pathak, V., \& Pathak, K. (2010). Reconfiguring the higher education value chain. Management in Education, 24(4), 166-171. https://doi.org/10.1177/089202061037679 1

Pepito, G. C., \& Acibar, L. B. (2019). SchoolBased Management and Performance of Public Elementary School Heads : Basis for Technical Assistance Plan. International Journal of Innovation and Research in Educational Sciences, 6(1), 67-83.

Rini, R., Sukamto, I., Ridwan, R., \& Hariri, H. (2019). School-Based Management in Indonesia: Decision-Making, Problems, and Problem-Solving Strategy.
International Conference on Progressive Education (ICOPE 2019), 422(47), 229235.

Santibañez, L., Abreu-Lastra, R., \& O’Donoghue, J. L. (2014). School based management effects: Resources or governance change? Evidence from Mexico. Economics of Education Review, 39 97-109. https://doi.org/10.1016/j.econedurev.2013 .11 .008

Sihono, T., \& Yusof, R. (2012). Implementation of School Based Management in Creating Effective Schools. International Journal of Independent Research and Studies, 1(4), 142-152.

The World Bank. (2007). What Is SchoolBased Management?

Vally, G. V. S., \& Daud, K. (2015). The Implementation of School Based Management Policy: An Exploration. Procedia - Social and Behavioral Sciences, $\quad$ 172, 693-700. https://doi.org/10.1016/j.sbspro.2015.01.4 21

Winarti, E. (2011). School-Based Management: the Challenges of Its Implementation in Indonesia. Orientasi Baru, 20(1), 85-106. 